\title{
On Editing Emily Dickinson
}

By

Per Winther

University of Oslo

In a sense Emily Dickinson became a poet only after her death. No more than seven of her poems were published in her lifetime. In 1890 appeared Pans by Emily Dideinsan, First Series, jointly edited by Mabel Loomis Todd and Thomas Wentworth Higginson, and this slender volume containing upwards of 100 poems was the first in a long and confusing series of Dickinson editions. Her most recent biographer, Richard B. Sewall, claims that "there is hardly a more erratic publishing record of a major poet in history." ${ }^{1} \mathrm{It}$ would lead too far to recapitulate that "erratic record" here." Suffice it to say that there still seems to be a need for an edition of Emily Dickinson's poetry which will render the poet a maximum of justice. ${ }^{3}$

Thomas H. Johnson's variorum edition was a landmark in that it was the first complete edition containing all her poems. ${ }^{4}$ But also this edition left a good many editorial problems unsolved, and it is to some of these problems that the present article addresses itself. Because of the vast number of articles on Emily Dickinson and her poetry, the editor of the most comprehensive Dickinson bibliography to date, Willis $\mathbf{J}$. Euckingham, recently called for articles which would "survey ... existing research" and "discuss special problems in Dickinson studies."5 The basic reason why editing Emily Dickinson becomes such a difficult task is of course the fact that she herself did not prepare her poems for publication, so that we are left with a very limited number of clues when it comes to establishing the poet's final intention.6 In terms of textual criticism Emily Dickinson is therefore in many ways a special case; much has been written about the particular problems relating to her manuscripts, and in the following an attempt is made to sum up this discussion and to suggest solutions to some of the problems involved. 
The first thing an editor of Emily Dickinson would have to decide is what kind of edition he wants: a scholar's edition or a reader's edition. Thomas H. Johnson's variorum edition is clearly an example of the former.Johnson set out to edit all the known Dickinson poems, and his aim was to include a maximum of information and to reproduce in as exact a form as possible Dickinson's poems. The variorum edition was widely praised by critics and scholars when it appeared, and, although in need of some revision, satisfies the demand for a scholar's edition.' What now remains is to produce an equally satisfactory reader's edition, a task which of course will entail a different set of problems since the editor of a reader's edition will have to be selective. His job is not to provide a maximum of information but to make Emily Dickinson's poetry as attractive as possible to the reader, while at the same time representing the poet as loyally as possibie.

One of the first problems such an editor will have to tackle is that of deciding which of the 1775 poems to include in a reader's edition, because to represent Dickinson fully is not necessarily the same as to render her the greatest justice. Critics agree that only a limited number of Dickinson's poems are successful creations. Charles $\mathrm{R}$. Anderson suggests that no more than a hundred of her poems could be called "really fine poems" and that only about twenty-five deserve the characterization "great."'s Frederick L. Morey, the editor of Emily Dickinson Bulletin, suggests that a definitive reader's edition should include some 350 poems. The New Critical approach of viewing each poem as an integral and self-sufficient whole will fail to do justice to Dickinson, Morey feels, and argues for a thematically arranged edition of this size "to show the fine shadings and contradictory moods on the same subject . . ."9

Morey's suggestion that a reader's edition should include more than the hundred or so poems indicated by Anderson seems reasonable. For one thing, no two editors would agree on which hundred poems to choose. Also, the reader will want to exercise his own critical talents, however amateurish they may be. It is possible therefore that what would materialize from a compromise between a purely qualitative selection and one based on the wish to represent fully, would be an edition of some 300 poems.

When the editor has made up his mind about which poems to include, he will have to settle on some principle of organization. The thematic ordering of the earliest editions has later been honored by critics like Anderson and Morey. Anderson chose a thematic 
approach for his study of Dickinson's work. Because so many of her poems are unusually short, he finds, "to survey the whole or concentrate on single lyrics runs an equal danger of scattering one's fire or pin-pointing too small a target." 10 His reasoning as a critic may also be brought to bear on the question of editorial strategy, and he has himself edited a selection of some seventy-five poems according to themes in a college anthology. ${ }^{11}$

The thematic approach makes good sense. It can no doubt help the reader to see Dickinson's "contradictory moods" on various subjects. However, the method has its disadvantages. For one thing thematic categories will often overlap. Poems which on the surface are love poems may for instance more rewardingly be read as comments on life after death. Secondly, and related to this, a thematic ordering of the poems involves interpretation. It is difficult to conceive of a thematic ordering which will go unquestioned by all readers of Dickinson's poetry. Given the nature of Emily Dickinson's poetry and the state of her manuscripts, any editor must also act as a literary critic. To the present writer it seems, however, that by opting for a thematic organization the editor would give greater priority to his hermeneutic functions than what is strictly necessary, and he should therefore look for some other way of ordering the poems.

That other way might be the one that is suggested by Emily Dickinson's own organization of her manuscripts. At one point in her life Emily Dickinson began arranging her poems into little "packets " or "fascicles" of four, five or six sheets of letter stationery. ${ }^{12}$ The packets were broken up during the first editing, but have later been restored to their original order through the painstaking work of, among others, Theodora Ward. Ruth Miller lists a total of 51 such packets, containing between 6 and 44 poems in each. ${ }^{13}$

The question of why Emily Dickinson chose to tie her poems in this way has intrigued commentators. One theory has it that this was the poet's substitute for publication and that the packets give us "her notion of the way her poems should be presented to the world when and if the world should be receptive."'14 But critics have been at a loss to explain what the guiding principle of the assemblage was. Ruth Miller has shown that it was not chronological, because there are poems which exist on scraps written in different hands that have been copied onto sheets in one hand before being included in a packet. $^{15}$ Nor were they assembled 
according to recipients, Miller finds, or according to single events or to subject matter.

Ruth Miller is the first critic to analyze the question of the packets in any depth. She claims that all the fascicles are very similar in construction, so similar in fact that "it seems possible to chart one and obtain a blueprint for all." Miller argues that the principle behind the fascicles is "dramatic," that although all the fascicles do not say the same thing, "they all do have an intrinsic dramatic narrative as their central structure." What ultimately emerges is therefore a long link-poem. Miller thinks Emily Dickinson got the idea of organizing her poems in this way from reading Francis Quarles' Emblems, Divine and Moral (1824 ed.). The most interesting thing about Emblems from Miller's point of view is its structure: "Each emblem is grouped around a single large theme and represents a religious drama, akin to Emily Dickinson's assemblage of poems into her own narrative of quest."

Miller's theory is interesting, and the reason why it is described in some detail here is that if it is tenable, it might provide an editor with a principle of organization for a reader's edition which presumably would reflect the poet's intention better than any other grouping of her poetry. However, the trouble with this theory is that it has never been adequately tested. Miller herself has demonstrated her thesis with regard to two packets only, fascicles 12 and 32. After a detailed analysis, which in itself is impressive enough, she comments, somewhat facilely, that "the degree to which each fascicle has its own inner design may be verified by anybody who cares to read the gatherings of poems as the poet intended."

The response of critics to Milier's theory has been ambivalent. George Monteiro calls it a "promising lead [which] cries for investigation." "16 Charles R. Anderson and Thomas Arp accept the theory, although Anderson is disappointed by Miller's limited demonstrations. David Porter is not convinced, however, and Sewall claims that "almost any random grouping of eighteen or twenty of ED's stronger poems can be shown to have [the kind of] coherence [pointed to by Miller], so recurrent are her major themes, images, and symbolic structures."17 Very recently a more comprehensive attempt has been made to test Miller's theory. In a dissertation Arlo Duane Sletto has investigated five fascicles, and in these he finds the kind of pattern that Miller suggested in her book. But Sletro admits that also his study is only a provisional one. ${ }^{18}$ Until a detailed investigation of all the fascicles materializes, 
one is more inclined to ascribe the kind of coherence that Miller and Sletto have found to the recurrence of major concerns, themes, structures, etc., that Sewall points to.

A prospective editor should examine Miller's theory very carefully to see whether or not her pioneering study has provided one of the few clues there are to the poet's intention. This does not mean that if he comes up with a positive answer all problems concerning organization are solved. A mere reproduction of the 51 packets would not do, simply because that would mean including too many of her less successful poems, so a selection would still have to be made.

A third way of confronting the problem of organization is to publish the poems in chronological order. One problem with this method is that the dating of some of the poems is uncertain. The chronology of Poems is widely accepted, however. ${ }^{19}$ Even though an editor who chooses a chronological way of presentation will come up against a few problems of dating, this method to my mind seems preferable because it is far less dependent on the editor's interpretation of Emily Dickinson's poems than the two methods outlined above. Working with a chronologically aranged edition, the reader will to a greater extent be his own critic and although he may initially find it difficult to trace developments, contradictory views or moods, it seems that once he has familiarized himself with the poems, he will find it more rewarding and stimulating to establish his own thematic categories instead of accepting blindly those of an editor.

A peculiarly Dickinsonian problem is the question of variants. Emily Dickinson was always engaged in a quest. Her mind was such that it never accepted absolutes, and intellectual and emotional ambiguity is one of the hallmarks of her poetry. It is therefore not surprising that she often should be equally undecided in the formulation of her questing thoughts, but through her indecision she created another set of problems for her editors to sort out. Often when she could not make up her mind which of a number of words or phrases to choose she left them all in the manuscript, as for instance in the poem "Promise This - When You be Dying" (No. 648), where Johnson lists as many as 20 variants for a poem of $\mathbf{3 3}$ lines. There are variants also for whole stanzas, a much cited example being "Safe in their Alabaster Chambers -" (No. 216). In cases like these it is of course impossible to establish final authorial intention since Emily Dickinson herself did not make up her mind. 
The choice in the case of variants must therefore perforce be left to the editor. What we, the readers, can hope for is an editor who combines great poetic sensibility and close familiarity with the workings of the poet's mind.

When Mabel Loomis Todd and Colonel Higginson started to prepare Emily Dickinson's manuscripts for the first edition, they felt that certain alterations of the original text were necessary to cushion the blow and minimize the shocking effect her unconventional verse was bound to have on the reading public. This gave lead to their "creative editing." Todd/Higginson substituted, as well as added and deleted, words in order to make the lines more regular and the rhymes more conventional. In some cases they also regularized what they considered grammatical lapses, for instance adding a third person -s where Emily Dickinson used an unorthodox non-finite form (often the subjunctive).$^{20}$

Some commentators feel that this "creative editing" is a defensible practice, that indeed Todd and Higginson often created better poems through their editing and that a modern editor is well advised to consider their suggestions along with those of the poet. ${ }^{21}$ This line of reasoning can be defended on purely esthetic grounds: it can be argued that the best version should be preferred, be it the version of the creative editor or that of the poet. Nevertheless, one hesitates to accept this practice. One's sense of piety is involved, but also the wish to become as initimate with the poet and her world as possible, and the distance between poet and reader is increased if her lyrics are tampered with by an editor.

A minor problem is Emily Dickinson's spelling, or rather her many misspellings. Some of these, Johnson asserts, she "carried through life with conscious relish for the sound of the local idicm: Febuary, boquet, bretheren." 22 One tends to agree with Anderson when he argues in favor of keeping these regional idiosyncracies. "These," he says, "were undoubtedly part of her deliberate strategy for speaking, as well as seeing, 'New Englandly'." Since there are relatively few such cases, he finds that it is better "to leave in an occasional slip... than to risk tampering with her idiom." "23 A different matter is her more obtrusive use of the apostrophe. She always wrote her contractions "does'nt, has'nt," and for the possessive of the personal pronoun "it" she invariable wrote "it's." 24 This cannot be said to be part of her idiom, and since these forms carry no extra meaning, an editor should feel free to regularize them. 
Emily Dickinson's extensive use of capital letters is a different matter, however. Higginson, who was one of the first to comment on this habit, assumed it to be a method of distinguishing nouns, analogous to Old English and German practice. ${ }^{25}$ This is not a satisfactory explanation, however; Emily Dickinson capitalized all parts of speech: not only nouns, but also pronouns, verbs, adjectives and even articles. ${ }^{26}$ The most eloquent attempt at explaining the capitals is the one made by John Crowe Ransom. He has found that Dickinson capitalized her key-words, and he characterizes this practice "as a way of conferring dignity upon [the poet's] objects, or as a mythopoetic device, to push them a little further into the fertile domain of myth."27 David T. Porter has demonstrated that this can be a warranted interpretation of Emily Dickinson's majuscules; in a convincing discussion of "There's a certain Slant of light" (No. 258), he shows how the poet enriches the meaning of her poem by her distribution of capital letters. ${ }^{28}$

But what are we to think of the many instances where Dickinson begins, for example, articles, auxiliary verbs, etc. (these can hardly be called key-words), with capital letters? As Porter and others have shown, her capitalization in many cases does not result from conscious artistic concerns, but must be seen as a rather whimsical habit of handwriting. At times she even uses capital letters in the middle and at the end of words. ${ }^{29} \mathrm{R}$. W. Franklin has also demonstrated that the same erratic use of capitals characterizes Emily Dickinson's trivial, definitely non-poetic scribblings, such as recipes and domestic notes. He concludes that Emily Dickinson was in fact conforming to the fashion of the times, and that for instance Mabel Loomis Todd in her letters revealed the same unorthodox distribution of her majuscules.

Since so many of the poet's majuscules must be considered whimsical and unimportant, it may be argued that an editor is best advised to drop them completely and only retain the more conventional ones at the beginning of lines. This is the practice adopted by James Reeves in his well-received edition. ${ }^{30}$ Yet, if one turns to Reeves' book after having lived with the variorum poems for some time, it is as if the lack of capitals makes Emily Dickinson's lines less alive; the poems are somehow not quite hers anymore. Again it seems therefore that the loyal editor who leaves the capitals in (except those occurring medially and finally) renders both the reader and the poet the greatest service. There are of course other than these somewhat sentimental reasons why the capitals should 
be kept. Not only does capitalization reinforce the meaning of important words; a similar effect is achieved with words which are normally considered unimportant. In the variorum edition Johnson represents the first stanza of poem No. 516 thus:

Beauty - be not caused - It Is -

Chase it, and it ceases -

Chase it not, and it abides -

The use of "Is" as a full verb rather than as an auxiliary in line one is reinforced through the capital letter and by also choosing the majuscule for "It" Dickinson made an unobtrusive phrase much more prominent than it would otherwise have been. In this poem, therefore, capitalization assists in bringing into focus the thematically most important phrase in the whole poem, an effect which would be reduced somewhat had the capitals been removed.

Even keeping the majuscules in articles does in some cases make perfect sense. The slight, but thematically significant function of a capitalized article is illustrated in "I started Early - Took my Dog" (No. 520). The first and the last stanzas read:

I started Early - Took my Dog -

And visited the Sea -

The Mermaids in the Basement

Came out to look at me -

Until We met the Solid Town -

No One He seemed to know -

And bowing - with a Mighty look -

At me - The Sea withdrew -

The poet has brought "The Sea" of the final line in contrast with "the Sea" of the second line in the first stanza through her capitalization. The meaning that "the sea" holds for the speaker is expanded throughout the poem. In the opening stanza what the speaker has in mind is obviously the physical sea, the ocean; in the final stanza the sea has become a gentleman, presumably a wooer, who politely bids the poetic persona farewell. The capitalized definite article in the last stanza thus both reinforces the personification and gives "The Sea" a prominence which corresponds to the enlarged meaning that it has taken in the speaker's mind. Although the cases of such more or less clear correspondence between meaning and the use of capital letters may be relatively 
rare, these and other examples nevertheless speak in favour of retaining all of Emily Dickinson's capitals for whatever little meaning they may convey.

In more than one way Thomas $\mathrm{H}$. Johnson introduced readers to a new Emily Dickinson through the variorum edition. One of the things that probably puzzled readers the most was the unorthodox punctuation. The variorum edition for the first time gave us a completely unpolished Emily Dickinson to the extent her idiosyncracies could be deciphered and typographically represented on the printed page. Johnson retained all occurrences of Dickinson's favorite punctuation mark, the dash, but he also represented faithfully all her other marks, even when these conventional marks were used in an unorthodox manner. Previous editors had regularized this aspect of the poet's style.

To deal with Emily Dickinson's conventional marks does not constitute much of a problem for the editor. We know that she cared about punctuation. H a draft for a letter, we find the following exclamation: "What a Hazard an Accent is! When I think of the Hearts it has scuttled or sunk, I almost fear to lift my Rand to so much as a punctuation." "31 There is also that often cited letter to Higginson in which she denounced an editorial revision in one of the seven poems that saw publication in her lifetime. In the poem "A narrow Fellow in the Grass" (No. 986), the editor of the Springfield Daily Republican, where it first appeared, inserted a question mark where Emily Dicltinson had no mark at all. Gommenting on this, she complained that the poem "was robbed of me - defeated too of the third line by the punctuation." "32 These two statements represent a clear instruction to the latter-day editor: to the extent that Emily Dickinson's conventional punctuation marks can be deciphered, they should be left the way she wrote them.

The question of what to do with the dashes, however, is a much more complex one. It is worthwhile to examine this problem in some detail, since the decision on what to do with the dashes is probably the one decision that will have the most far-reaching consequences for the editor of a reader's edition. Whatever strategy he chooses to follow, almost every poem in the variorum edition will be affected since Emily Dickinson used dashes all throughout her life.

A number of commentators have written at great length on this aspect of Emily Dickinson's punctuation. Johnson found that they do not have a grammatical function; rather they seem to approxi- 
mate a representation of a musical beat. ${ }^{33}$ This idea is supported by Austin Warren, who sees the dashes as sometimes "equivalent to the phrasing marks of music." 34 In the same vein, Charles R. Anderson characterizes the dashes as "an attempt to create a new system of musical notation for reading her verse." 35

The most radical interpretation of the dashes is probably the one given by Edith Wylder. Her theory holds that the dashes are rhetorical or elocutionary symbols; she distinguishes between four basic symbols, which she represents thus: $(-),(/),(\backslash),(\cup)$, the horizontal mark (-) signalling a monotone, the angular slant (/) a rise, etc. Dickinson's dashes, Wylder argues, are meant to direct how the poems are to be read. Dickinson was concerned, Wylder says, "that her written lines . . . communicated her meaning as fully and with the same sense of immediacy as if she had spoken them." 36 Dickinson's four basic elocutionary symbols were used in several rhetorical readers that were popular in New England in the middle of the nineteenth century, and one of them was the standard textbook at Amherst Academy at the time Emily Dickinson attended classes there. These facts Wylder cites as conjectural evidence to support her theory. In her book Wylder sums up the basic rules and principles of nineteenth-century elocution and then, on the basis of these rules, goes on to explain how the dashes carry extra-verbal meaning in terms of inflection, rhetorical pauses and emphasis.

It is beyond the scope of the present paper to examine closely Wylder's theory. Certain aspects of the theory agree with the ideas on Dickinson's punctuation voiced by other scholars. LindbergSeyersted invokes Johnson, Anderson, and Warren and their theories about the dashes representing a kind of musical notation in stressing the connection between the rhythm of Dickinson's verse and her punctuation. This seems to match Wylder's theory of rhetorical pauses. Also Lindberg-Seyersted concludes that intonation is signalled through Dickinson's use of the dashes, a concept which is closely related to Wylder's theory of inflection. ${ }^{37}$

However, there is a certain neatness about Wylder's findings which makes it hard to accept her theory in toto. LindbergSeyersted pointed to this problem in her discussion of Wylder's theory the way it was initially stated: "How can we accommodate the different roles that the marks appear to take in different contexts?" Lindberg-Seyersted demonstrates that the theory may seem to fit in one poem, but then "words which would, according to the [Wylder] system, require the same kind of rhetorical mark, are 
unexpectedly followed by other signs." 38 There is furthermore one set of arguments against the elocutionary theory which Wylder fails to discuss in her book, arguments which need to be gainsaid for us to fully believe in her findings. ${ }^{39} \mathrm{~W}$ ard, Lindberg-Seyersted, and Franklin have pointed out that Dickinson sprinkled her pages with dashes when writing letters, household notes, shopping lists, recipes, and even when copying passages from books she added dashes that were not there in the original. Franklin concludes, justly it seems, that the dashes form an integral part of her handwriting. ${ }^{40}$ Clearly these findings should serve as a warning against establishing neat theories of the kind that Edith Wylder advocates.

Should one then disregard the dashes altogether? Or should they at least be regularized? Some critics have answered these questions in the affirmative. Austin Warren's suggestion is that all punctuation, except that of the period, should be omitted "after the fashion of some contemporary poetry." This is a method, he posits, "which would not, in any case $\mathbb{I}$ can summon up, obscure the comprehension of her poetry." 41 This may be so in many cases, but Franklin has shown that Warren's system put into practice may indeed obscure comprehension. He reproduces a poem (No. 297) edited in the Warren manner by a German critic, Kurt Oppens, and demonstrates that Oppens has made the syntax misleading by removing punctuation and capitals. ${ }^{42}$ In a sense Warren's stance is illogical, since it comes as a conclusion to a convincing analysis of the effect that the dashes have in one Dickinson poem. He finds that the dashes reproduce pauses in her own reading (reading, then, surely in the Wylder sense of the word) and "render the clauses and phrases a fluidity of transition lost by a rigid system." 43

The discussion of what to do with the dashes may seem redundant in light of the evidence cited above : since the dashes evidently are a habit of Emily Dickinson's handwriting, it may seem rather obvious that the punctuation should be regularized, because surely, we are not interested in that habit per se. The fact that Dickinson has been edited successfully with conventional punctuation and capitalization even after the appearance of the variorum edition, notably in James Reeves' fine selection, would also seem to support the idea that her punctuation should be regularized in a reader's edition. Yet, there are cases where the normalized versions fail to do Dickinson complete justice. In the final line of stanza one in "Exultation is the going" (No. 76) the variorum edition has a dash instead of Reeves' period ("Into deep Eternity -"). A period here, 
it seems to me, would almost work counter to the intended meaning; the dash reinforces the idea of something neverending, whereas the period has the opposite effect. Or take the poem I have discussed above in a different context, "I started Early - Took my Dog _-" (No. 520), a poem with no other punctuation marks than the dashes. To regularize the punctuation is impossible without some element of interpretation. By introducing conventional marks instead of dashes, the editor must for instance sort out the syntax, something which is left to the individual reader if the dashes are kept. Unfortunately interpretations are seldom unequivocal, and there are times when editor and reader will disagree. In poem No. 520 Reeves chooses to read line one of the final stanza together with the preceding stanza, since hc puts a period at the end of this line:

$$
\text { ... then my shoes }
$$

Would overflow with pearl,

Until we met the solid town.

No one he seemed to know

And bowing with a mightly look

At me, the sea withdrew.

This surely limits the possibilities of interpretation. The variorum edition has dashes at the end of the Iast five lines of the poem and to the present reader it makes as much sense to link the line, "Until we met the solid town," to the last three. Or the line may be read as referring to the penultimate as well as the final stanza. An edition which does not force any one of these interpretations on the reader seems desirable, and this can best be achieved by leaving the dashes the way the poet wrote them. There are not many such cases in Reeves' edition, but this example does give an indication of the kind of problems a regularized edition may run into. There is also another reason why Dickinson's dashes may be preferred to Reeves' commas, semicolons, and full stops. The experiences related by the poetic persona have clearly sexual overtones: the personified sea is male and the description of how the speaker is overtaken by the tide is very physical. The dashes give the lines a certain breathlessness, which matches beautifully the content of the poem. It seems that this extra-verbal sense is lost in Reeves' regularized version. ${ }^{44}$

One cannot always point to such correspondence between form and content in Emily Dickinson's poems, and one has to conclude 
that the correspondence often is too slight to really matter, or does not exist at all, a conclusion which is borne out by Dickinson's use of the dashes in clearly non-literary contexts. Nevertheless one would not like to see the dashes removed from a reader's edition. There are at least some cases where we can say that the dashes convey meaning, which in itself is a strocg argument in favor of retaining them. Those cases where such meaning does not seem to exist should be given the benefit of the doubt; the reader will want to sort out the meaningful cases for himself and this he can only do if the editor gives him the poems in a form that matches the original manuscripts as closely as possible.

Unfortunately the dashes cause other editorial problems as well. First of all the editor has to decide when to print a dash or to use a conventional mark of punctuation. Secondly, the dashes take on a number of different shapes, and it is difficult to find a printing type which can represent them all. Lindberg-Seyersted has pointed out that the manuscript dashes are often very short marks and that it is difficult to represent them by use of conventional types. ${ }^{45}$ It is therefore clear that in this, as in so many other matters pertaining to the editing of Emily Dickinson's manuscripts, one must not ask for perfection. The editor should work on the basis of the conventions established by the variorum edition. Poems enjoys an authority which makes it the basic point of orientation for anyone who works with Dickinson's poetry and therefore these conventions will be recognized by a large number of readers (also Johnson's The Complete Poems of Emily Dickinson and Final Harvest conform to the practice $\mathbf{f}$ the variorum edition).

The overall view underlying the present article is in a sense purist. With very few exceptions the editor of a reader's edition should reproduce as carefully as possible the typically Dickinsonian features, the capitals and her punctuation; in terms of organization, a chronological arrangement seems preferable. The purist view is motivated by two basic concerns. Some element of interpretation on the part of the editor is unavoidable, but it should be kept to the barest minimum. This, it seems, can best be achieved by choosing the editorial strategies advocated above. Secondly, a reader's edition should render the uniqueness of Emily Dickinson's poetry to the extent this is feasible, given the constraints of printing conventions. Having worked with the variorum edition for some time, one learns to appreciate a certain vivaciousness, an im- 
mediacy, which is somehow lost in regularized versions of her poems. Whatever initial discomfort one may experience in adjusting to Emily Dickinson's idiosyncracies, the rewards in terms of heightened poetic experience compensate amply for the efforts necessary to make that adjustment. In matters where a purist attitude is less easily brought to bear, such as the question of which poems to include and which variants to choose, one can only hope for an editor who has worked closely and lor a long time with Emily Dickinson's "Letters to the World," who has developed an intuitive kaowledge of the workings of the poet's mind, and who can add to this a poetic sensibility of his own. To edit a collection of Emily Dickinson's poems according to these principles is no doubt a formidable task, but one for which the poetry reading public will be forever grateful.

\section{N O T E S}

1 Richard B. Sewall, The Life of Emily Dickinson, 2 vols. (New York: Farrar, Straus and Giroux, 1974), I, 234.

2 For a full survey of the many editions of Emily Dickinson's poetry, see Millicent Todd Bingham, Ancestors' Brocades: The Literary Debut of Emily Dickinson (New York and London: Harper and Brothers Publishers, 1945), and R. W. Franklin, The Editing of Emily Dickinson: A Reconsideration (Madison: The University of Wisconsin Press, 1967).

3 This need is voiced, for example, in Donald E. Stanford's article "On Editing Emily Dickinson," The Southern Review, 5 (Spring, 1969), xvii-xix, and in Frederick L. Morey, "The Reader's Edition," Emily Dickinson Bulletin, No. 23 (First Half, 1973), pp. 144-155.

4 Thomas H. Johnson, ed., The Poems of Emily Dickinson, Including Variant Readings Critically Compared with All Known Manuscripts, 3 vols. (Cambridge, Mass.: The Belknap Press of Harvard University Press, 1955). This edition will hereafter be referred to as Poems or "the variorum edition"; number references to individual poems in this edition will appear parenthetically in the text.

5 Willis J. Buckingham, "The Bibliographical Study of Emily Dickinson," Resources for American Literary Study, 4 (1974), 57-71.

6 General works on editorial procedures offer little help for the editor of Emily Dickinson's poems. For instance Fredson Bowers' advice on how to establish the basic text for an edition presupposes two things, neither of which applies to Emily Dickinson: either the poet has published or she has at least prepared manuscripts for the printer; see Fredson Bowers, "Textual Criticism," in James Thorpe, ed., The Aims and Methods of Scholarship in Modern Languages and Literatures (New York: Modern Language Association of America, 1970), 2nd ed., pp. 29-54.

7 See for instance Franklin, pp. 104-113 on the need for revisions.

8 Charles R. Anderson, Emily Dickinson's Poetry: Stairway of Surprise (New York: Holt, Rinehart and Winston, 1960), pp. xiii-xiv.

9 Frederick L. Morey, "The Reader's Edition," p. 153. See also Morey's "Emily Dickinson Criticism: Is It a Waste?" Emily Dickinson Bulletin, No. 27 (First Half, 1975), pp. 74, 77.

10 Anderson, p. xii. 
11 Charles R. Anderson, ed., American Literary Masters, Vol. I (NewYork: Holt, Rinehart and Winston, 1965), 988-1019.

12 See Thomas H. Johnson, Emily Dickinson: An Interpretive Biography (Cambridge, Mass.: The Belknap Press of Harvard University Press, 1955), p. 69.

13 Ruth Miller, The Poetry of Emily Dickinson (Middletown, Conn.: Wesleyan University Press, 1968), pp. 247-248, 290.

14 Sewall, The Life of Emily Dickinson, II, 537.

15 Miller, p. 248. The following is a summary of some of the main points in a chapter (10) of Miller's book which deals exclusively with the fascicles.

16 George Monteiro, "The One and Many Emily Dickinsons," American Literary Realism, 7 (Spring, 1974), 140.

17 Anderson reviewed Miller's book in American Literature, 41 (March, 1969), 125-129. The other reviews of Miller's book that I mention appear as follows: The New England Quarterly, 42 (June, 1969), 281-284 (Arp); Criticism, 11 (Winter, 1969), 97-100 (Porter); Sewall comments on Miller's thesis in The Life of Emily Dickinson, II, $538 \mathrm{n}$.

18 Arlo Duane Sletto, Emily Dickinson's Poetry: The Fascicles (New Mexico University, 1975); unpublished doctoral dissertation. Sletto comments on the provisional nature of his study in the abstract of his thesis appearing in Dissertation Abstracts International (1975), p. 3719-20-A. My comments on Sletto's dissertation are based on this abstract.

19 For a discussion of the methods used to establish the chronology, see Poems, I, xlix-lix, ixi-lxii.

20 See Poems, I, xliv-xlviii, and Franklin, pp. 22-26.

21 See Stanford, p. xix.

22 Poems, I, lxii-lxiii.

23 Anderson, p. 301.

24 Poems, I, lxiii.

25 T.W. Higginson, "Emily Dickinson's Letters," Atlantic Monthly, 68 (October, 1891), 444.

26 See Brita Lindberg-Seyersted, The Voice of the Poet (Cambridge, Mass.: Harvard University Press, 1968), p. 181.

27 John Crowe Ransom, "Emily Dickinson: A Poet Restored," Perspective USA, No. 15 (Spring, 1956), p. 6.

28 David T. Porter, The Art of Emily Dickinson's Early Poetry (Cambridge, Mass.: Harvard University Press, 1966), pp. 140-142.

29 See Franklin, p. 120. The other referencesare to pp. 124 and 121 of Franklin's book.

30 James Reeves, ed., Selected Poems of Emily Dickinson (London:William Heineman Ltd., 1959).

31 Thomas H. Johnson and Theodora Ward, eds., The Letters of Emily Dickinson (Cambridge, Mass.: The Belknap Press of the Harvard University Press, 1958), III, 887; cf. Edith Wylder, The Last Face: Emily Dickinson's Manuscripts (Albuquerque: University of New Mexico Press, 1971), p. 15.

32 Letters, II, 450. In a note to this poem in the variorum edition Johnson claims that the editorial change consisted in adding a comma rather than a question mark. Brita Lindberg-Seyersted asserts, however, that both in the Spring field Daily Republican, where the poem first appeared, and in the Springfield Weekly Republican, the poem appears with a question mark; see Brita Lindberg, "Emily Dickinson's Punctuation," Studia Neophilologica, 37, No. 2 (1965), 348-349.

33 Poems, I, lxiii.

34 Austin Warren, "Emily Dickinson," The Sewanee Review, 65 (OctoberDecember, 1957), 566. 
35 Anderson, p. 306.

36 Edith Wylder (the former Edith Perry Stamm) first stated her elocutionary theory in a brief article entitled "Emily Dicltinson: Poetry and Punctuation," The Saturday Reviewe (March 30, 1963), pp. 26-27 and 74. Theodora Ward dismissed the theory on the grounds that Dickinson used the same punctuation marks in her letters; see Ward's answer to Wylder in "Poetry and Punctuation," The Saturday Review (April 27, 1963), p. 25. Brita Lindberg-Seyersted also raised serious questions about the theory and pointed to the lack of demonstration in Wylder's initial article; see Brita Lindberg, "Emily Dickinson's Punctuation," pp. 341-347. In her book Wylder attributes this controversy to the lack of emphasis in her first article on "how to understand what we read" rather than "how to read aloud"; see The Last Face, pp. 2-7.

37 "Emily Dickinson's Punctuation," p. 358.

38 Ibid., pp. 344, 345-46.

39 Wylder is aware of these counterarguments, because she refers to the places where they appear; see The Last Face, p. 4, n. 8.

40 See Ward, "Poetry and Punctuation," p. 25; Lindberg, "Emily Dickinson's Punctuation," p. 347; and Franklin, pp. 119-125.

41 Warren, p. 567.

42 Franklin, pp. 125-126.

43 Warren, p. 567.

44 In her article on Dickinson's punctuation (pp. 339-40), Lindberg-Seyersted offers a similar analysis of how Ransom and Reeves' regularization of "I heard a Fly buzz - when I died _." slightly mars the tone and extra-linguistic meaning of the poem.

45 "Emily Dickinson's Punctuation," p. 354.

I would like to thank Dosent Brita Seyersted for the valuable advice I have received from her throughout the writing of this article. Professors Per Seyersted and Kristian Smidt have kindly read the manuscript and have offered usefulsuggestions for revisions. 